\title{
Susceptibility of European pear genotypes in a gene bank to pear psylla damage and possible exploitation of resistant varieties in organic farming
}

\author{
Benedek, P. ${ }^{1}$, Szabó, T. ${ }^{2}$, Nyéki, J. ${ }^{3}$, Soltész, M., Szabó, Z. $^{3}$ \& Konrád-Németh, C. ${ }^{4}$ \\ ${ }^{1}$ University of West Hungary, Faculty of Agricultural ad food Sciences, \\ H-9200 Mosonmagyaróvár, Vár 4. (e-mail: benedek@mtk.nyme.hu) \\ ${ }^{2}$ Research and Extension Centre for Fruit Growig, H-4244 Úfehértó, Vadastag 2. \\ ${ }^{3}$ Institute of Extension and Development, University of Debrecen, H-4032 Debrecen, Böszörményi út 138. \\ ${ }^{4}$ Gyümölcskert Zrt., H-8800 Nagykanizsa, Csengery út 90.
}

\begin{abstract}
Summary: We evaluated 285 pear genotypes (commercial cultivars, ancient local varieties, unnamed local strains, seedlings, wild seedlings) in the largest gene bank of pear in Hungary from the point of view of psylla resistance to explore their possible exploitation in organic farming. We have found some 10 new resistant types (Bókoló körte, Bötermö Kálmán, Füge alakú körte, Nagyasszony körte, Nyári Kálmán, Rozs nyári körte, Viki körte, Pb-242, Pb-299, 0-632) and 7 highly tolerant ones (Cure-6, Kései Kálmán, Kieffer, Kieffer Éd, Steiner, Téli Kálmán, II. B-3$6 / 4,96-16 / 5)$ (Table 1). These made up $3.5+2.8$ per cent of the investigated genotypes, while 93.7 per cent of them were susceptible to pear psylla damage. Taking earlier and present results into account we can list more than 30 European pear cultivars being resistant or highly tolerant to pear psylla infestation and damage. In fact, the list of resistant and highly tolerant cultivars may serve as a basis selecting pear cultivars fitting to the specific requirements of the organic farming. By the end we can conclude that there is some real hope to exploit some resistant or highly tolerant ancient or local cultivars in organic farming but further investigations are needed to estimate their yield capacity and fruit quality.
\end{abstract}

Key words: pear genotypes, pear psylla, resistance, susceptibility, organic farming

\section{Introduction}

Since the time when Westigard et al. (1970) have discovered that Asian pear species - Pyrus betulifolia, $P$. calleryana, P. faurieri, P. ussuriensis, $P$. x bretschneideri are resistant to the pear psylla (Cacopsylla species) there is an increasing interest towards the possible resistance of different pear genotypes against this very serious pests of pear production. Harris (1973) investigated the psylla resistance of interspecific pear hybrids and established their resistance to this pest. Although interspecific hybrids have been found to be resistant to pear psylla in other studies, too (Bell \& Zwet 1998, Robert \& Raimbault 2005, Bell 2009), the bad quality of their fruit limits their usefulness in breeding programmes (Robert \& Raimbault 2005) and in commercial production.

Quamme (1984) evaluated several pear species and also a number of European per cultivars from the point of view of psylla resistance and has found some of them to be more or less resistant to this pest. Several authors investigated great many further European pear genotypes in the past twenty five years (Quarta \& Puggioni 1985, Briolini et al. 1988, Butt et al. 1988, Berrada et al. 1995, Puterka et al.1993, Kocsisné et al. 2005, Robert \& Raimbault 2005, Bell \& Stuart 1990, Bell 1992, 2003, Bell \& Puterka 2004, Sestras et al. 2009, Bell
2009) and detected several cultivars, clones, wild seedlings, ancient and local genotypes to be resistant or highly tolerant to this pest. Most studies were made with field observations (Quarta \& Puggioni 1985, Briolini et al. 1988, Berrada et al. 1995, Puterka et al.1993, Kocsisné et al. 2005, Robert \& Raimbault 2005, Sestras et al. 2009, Bell 2009) and great many studies were made in the laboratory, too, by rearing psylla larvae on plant material (Harris 1973, Butt et al. 1988, Bell \& Stuart 1990, Bell 1992, 2003, Puterka et al 1993, Bell \& Puterka 2004).

Most authors agree that commonly grown European pear cultivars are highly susceptible to the pear psylla damage (e.g. Quarta \& Puggioni 1985, Robert \& Raimbault 2005). No more than a minor part of the investigated genotypes have been found to be resistant or at least of low susceptibility (e.g. Quarta \& Puggioni 1985, Bell \& Stuart 1990, Robert \& Raimbault 2005, Sestras et al. 2009). One Italian cultivar, Spina Carpi, that was found to be of low susceptibility by Quarta \& Puggioni (1985), was regarded to be resistant by other authors, too (Briolini et al. 1988, Robert \& Raimbault 2005).

As far as the reasons of resistance to pear psylla damage are concerned Harris (1973) has pointed out that it is the consequence of ovipositional dispreference and increased nymphal mortality on resistant genotypes. Butt et al. (1988) 
stated that in laboratory studies psyllas probed to feed on resistant genotypes but finally they left the plant or died after little feeding. Similarly reduced larval feeding as well as increased larval mortality or increased movement off the plants was detected on resistant genotypes in a number of other studies (Bell \& Stuart 1990, Bell 1992, 1993, Puterka et al. 1993, Bell \& Puterka 2004). Accordingly, inspection of larval mortality on psylla larvae reared on plant material seems to be the most reliable method to test host resistance in the laboratory (e.g. Butt et al 1988, Bell \& Stuart 1990).

Bell \& Puterka (2004) reviewing the modes of host plant resistance to pear psylla damage have shown that it is a rather a complex phenomenon. They established that the host resistance is a combined consequence of three different effects. The first effect is ovipositional antixenosis because adults lay much less eggs on resistant genotypes. The second factor is feeding atixenosis because psyllas show reduced frequency of feeding on resistant pear. The third factor is antibiosis that is a complex phenomenon itself, comprised of increased larval mortality, delayed (elongated) larval development, reduced larval (nymphal) weight and reduced fecundity of females. Feeding antixenosis has been established as the key factor of resistance because it is associated with reduced egg laying and increased larval mortality as well as delayed larval development.

So there are results in the literature hold out a promise to utilize resistant pear genotypes in organic farming where traditional plant protection measures are greatly restricted and resistant genotypes would help to neglect pesticide applications. Unfortunately, the fruit quality of many resistant European pear germplasms is poor (Bell \& Zwet 1998), similarly to the resistant interspecific hybrids (Robert \& Raimbault 2005). Hence we decided to evaluate pear genotypes in the largest gene bank of pear in Hungary from the point of view of psylla resistance to explore their possible exploitation in organic farming. The main intention in this study was to classify all the examined genotypes according to their resistance, tolerance or susceptibility and to find out completely resistant strains with acceptable fruit quality, if possible. However, the investigated gene bank contained few widely grown commercial cultivars, because most of the trees belonged to ancient cultivars, local varieties, unnamed local strains, seedlings, and wild seedlings. Therefore we made some additional observations on some greatly favoured commercial pear cultivars in a big fruitgrowing farm.

\section{Material and method}

We carried out field investigations in the largest gene bank of pear in Hungary that situated in the experimental area of the Research and Extension Centre for Fruit Growing at Újfehértó, North-Eastern Hungary. The gene bank was planted at a sandy area being typical of the region.

The trees (two trees of each genotype) were planted from 1984 to the recent years. There are 486 pear genotypes in the collection. More than half of the trees were at least 10-12 years old in 1996 when we started the observations but the rest of them were younger. We selected those 285 genotypes for investigations the trees of which were relatively uniform in age; all of them were 10-12 years old when the investigations were begun. Younger trees were not included in the research. Trees were medium sized; most of them were grafted to quince as rootstock.

Investigations were made during two periods of time, the first period was from 1996 to 1999 and the second period from 2004 to 2008. This is nine years altogether. Most genotypes were observed all along the nine years, but a part of them was neglected for one year and some others for two years for the lack of necessary manpower. So, most genotypes were observed during 9 years, some ones for 8 and a portion of them for 7 years.

The gene bank received an integrated plant protection program all along the experimental period; it received greatly reduced pesticide application with pesticides being relatively safe to the environment. The pesticides applied changed slightly during the long period of experimentation because pesticide regulations changed meanwhile for EU decisions.

All trees were sampled for psylla infestation in midAugust each year because this is the top period of psylla infestation in this region. We counted the ratio of infested shoots at the four points of the compass at each tree using a 5 grade scale as follows:

0 : no infestation

1: ratio of infested shoots is $1-3 \%$

2: ratio of infested shoots is $3-8 \%$

3: ratio of infested shoots is $8-15 \%$

4: ratio of infested shoots is $15-50 \%$

5: ratio of infested shoots is $50-100 \%$

Evaluating the results we calculated the mean infestation levels of each genotype for the two periods of investigations (1996-1999, 2004-2008) and for the total time of observations (9, 8 or 7 years). All mean infestation levels and also the minimum and maximum infestation scale values during the whole observation period were taken into account during the analysis. Taking all these figures into account all investigated genotypes were classified into the following categories of resistance/susceptibility:

I. Resistant (no infestation): Mean scale values of infestation were 0.0 during the 9,8 or 7 years of investigations, because no infestation occurred during the whole period (scale value 0 ), when other genotypes - usually adjacent trees - were moderately or highly infested.

II. Highly tolerant (negligible infestation): Mean scale values of infestation were as low as $0.1-0.4$ during the 9,8 or 7 years of investigations. There was no infestation in most years (scale value 0), and negligible, minor infestation (scale value 1) appeared in one or two years only during the whole period of observations.

III. Slightly susceptible (light damage): Mean scale value of infestation was $0.4-1.0$ during the 9,8 or 7 years of investigations. There were some years with no infestation at several genotypes (scale value 0 ) but in other years we found some infestation (scale values 1 or 2 , and exceptionally 3 ), 
the highest values of infestation were scale values 2, or exceptionally 3 .

IV. Susceptible (medium damage): Mean scale values of infestation were 1.1-2.1 during the 9,8 or 7 years of investigations. Infestation values varied between scale values 0 to 5 in different years, but scale value 0 occurred very rarely (in at least one year during the whole observation period). In fact, infestation levels were greatly varying during consecutive years.

V. Highly susceptible (heavy damage): Mean scale values of infestation were 2.2-2.9 during the 9,8 or 7 years of investigations. Infestation values varied between scale values 1 to 5 in different years, but scale value 1 occurred very rarely (in at least one year during the whole observation period).

Additional observations were made on four widely grown commercial pear cultivars (Packams' Triumph, Bosc kobak, Bartlett [Hungarian name: Vilmos körte], Abate Fétel) with good yield capacity and good fruit quality in a large commercial farm in South-Western Hungary, Gyümölcskert Kft., Nagykanizsa. The plantations were situated at two sites fairly close to each other. Pear psylla infestation was inspected three to four times during the growing season. Two trees were sampled for each cultivar at each inspected orchards and the ratios of infested shoots at the four points of the compass were registered using the same 5 grade scale as above. All the four inspected cultivars were found to be highly sensitive to pear psylla damage in earlier studies made at different part of Europe. The inspected cultivars received intense, standard plant protection treatments according to the best farm technology elaborated to this region.

\section{Results}

Pear psylla infestation was rather changeable during the long period of observations. Slight infestation was measured in the years of 1998-1999 and 2004-2005, while much heavier damage occurred in 1996-1997 and 2006-2008. It was very important that the period of observations was as long as 9 (or 7-8) years because this way we were able to inspect the reaction (susceptibility) of genotypes to pear psylla infestation under various pressures of infestation. When infestation pressure was low little differences were detected among genotypes but when the infestation pressure rose to be high definite differences could be detected.

We have found 10 genotypes to be resistant to pear psylla damage (Table 1) that gave 3.5 per cent of the inspected cultivars (Table 2). Seven of these are ancient local cultivars, fortunately most of them with acceptable yield and fruit quality. The remaining 3 genotypes were unnamed wild seedlings from different localities.

The number of highly tolerant genotypes was only 7 (Table 1) that gave 2.8 per cent of the cultivars investigated (Table 2). There were 4 ancient cultivars among them (one of these was represented by two types from different localities) and 2 unnamed genotypes.
As much as 28 genotypes were falling into the category of slightly susceptible that suffered only light damage by pear psylla during the years of observations (Table 2). These genotypes collectively made up 9.8 per cent of the investigated types of pear (Table 2). Most of them were ancient local varieties, no more than two of them were widely grown cultivars and a single one was an unnamed genotype.

The bulk of the genotypes investigated were classified as susceptible, because all of them suffered medium damage by pear psylla during the years of investigations. The number of susceptible genotypes was as much a 208 of the 285 ones investigated (Table 1), that made up 72.7 per cent of the investigated types (Table 2). There were 8 widely grown commercial cultivars among them and 11 unnamed genotypes, while the vast majority of them (189) were local varieties or ancient cultivars of some specific geographical regions.

The number of highly susceptible cultivars, that suffered heavy damages by the pear psylla in most years, was 31 (Table 1), that was 10.9 per cent of all of the cultivars investigated (Table 2). Most of these were local varieties and ancient cultivars but there were 3 widely grown cultivars and a single unnamed genotype, too.

Pear psylla infestation of the four widely grown sensitive, commercial cultivars (Packams' Triumph, Bosc kobak, Bartlett [Hungarian name: Vilmos körte], Abate Fétel) inspected in the large commercial fruit growing farm was well measurable (Table 3) despite the effect of standard (intense) plant protection measures applied at this farm for commercial production. Although most (generally 64 to 78 per cent) of the shoots were free of this pest all along the season, a good deal of them was slightly (scale values 1 and 2) or moderately infested (scale values 3 ) and some heavily infested trees/shoots occurred too (scale value 4 and 5) at least in a small per cent ratio (Table 3). This meant that with the help of intense plant protection applications we were able to control pear psylla damage at an acceptable level but we were unable to prevent infestation because of the susceptibility of cultivars.

\section{Discussion and conclusions}

The method we applied can be considered as subjective ratings (scoring) of infestation. Bell (2009) who compared both subjective ratings and objective counts (of eggs and nymps) concluded that subjective rating having been made in consecutive years were correlated fairly well (high or moderately high correlations) to the objective counts. So it can be stated that subjective scoring of infestations during several year periods can result in reliable results on resistance or susceptibility of pear genotypes to pear psylla infestation and damage. We have found - and other authors also reported (e.g. Kocsiné et al. 2005, Bell 2009) - that infestation level can be greatly different in consecutive years. For this reason, "in site" investigation in the orchards 
Table 1. Susceptibility of pear genotypes (commercial cultivars, ancient local varieties, unnamed local strains, seedlings, wild seedlings) to pear psylla infestation and damage (Újfehértó gene bank: 1996-1999, 2004-2008)

\begin{tabular}{|c|c|c|c|c|c|}
\hline \multicolumn{6}{|c|}{ Resistance/susceptibility level of genotypes } \\
\hline $\begin{array}{c}\text { I. Resistant } \\
\text { (no infestation) }\end{array}$ & $\begin{array}{l}\text { II. Highly tolerant } \\
\text { (negligible } \\
\text { infestation) }\end{array}$ & $\begin{array}{l}\text { III. Slightly } \\
\text { susceptible } \\
\text { (light damage) }\end{array}$ & \multicolumn{2}{|c|}{$\begin{array}{l}\text { IV. Susceptible } \\
\text { (medium damage) }\end{array}$} & $\begin{array}{l}\text { V. Highly susceptible } \\
\text { (heavy damage) }\end{array}$ \\
\hline $\begin{array}{l}\text { Bókoló körte } \\
\text { Bötermő Kálmán } \\
\text { Füge alakú körte } \\
\text { Nagyasszony körte } \\
\text { Nyári Kálmán } \\
\text { Rozs nyári körte } \\
\text { Viki körte } \\
\text { Pb-242 } \\
\mathrm{Pb}-299 \\
\text { 0-632 }\end{array}$ & $\begin{array}{l}\text { Cure-6 } \\
\text { Kései Kálmán } \\
\text { Kieffer } \\
\text { Kieffer Éd } \\
\text { Steiner } \\
\text { Téli Kálmán } \\
\text { II. B-3-6/4 } \\
\text { 96-16/5 }\end{array}$ & $\begin{array}{l}\text { Adonyi körte } \\
\text { Adonyi téli körte } \\
\text { Alma alakú körte } \\
\text { Angonlemi Szentendre } \\
\text { Bálint öszi körte } \\
\text { Bikedi öszi körte } \\
\text { Cukor körte } \\
\text { Cserlevelü császár } \\
\text { Droudard } \\
\text { Eliz asszony } \\
\text { Fillér körtéje } \\
\text { Gerjén nyári körte } \\
\text { Gheler } \\
\text { Hosszúréti ókörte } \\
\text { Korai Klapp } \\
\text { Muskotályos vajkörte } \\
\text { Nyári bergamott } \\
\text { Nyári Nagytétény } \\
\text { Nyári Nyakas Bicske } \\
\text { Óriási körte Bicske } \\
\text { Pomázi nyári } \\
\text { Pöttyös körte } \\
\text { Téli zöld körte } \\
\text { Új Pointeau } \\
\text { Váraljai körte } \\
\text { Zsír körte } \\
\text { 2/8. }\end{array}$ & 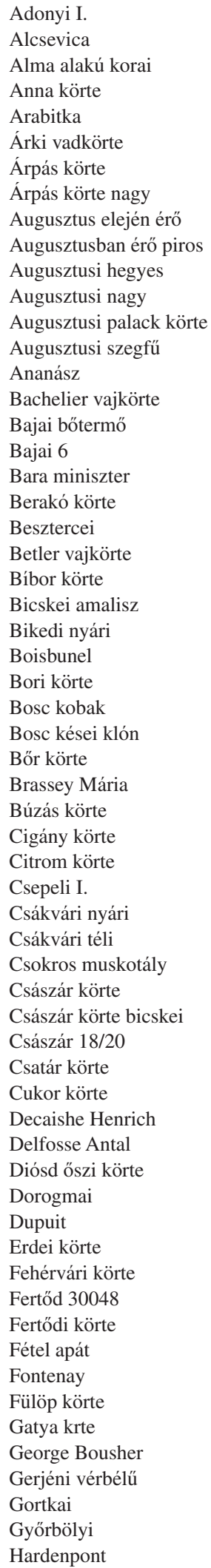 & 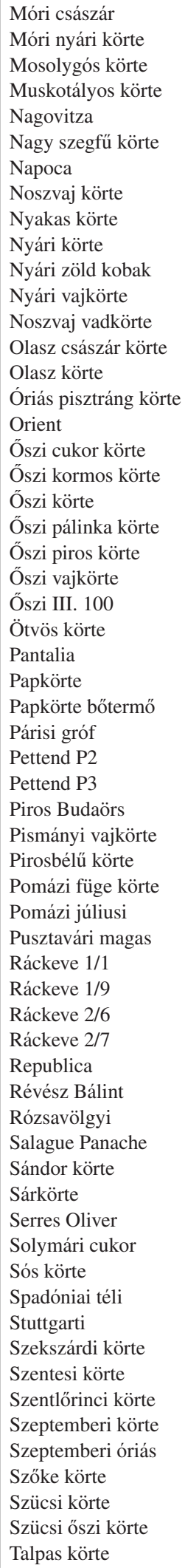 & $\begin{array}{l}\text { Alma körte } \\
\text { Aurora } \\
\text { Bácskai nagy szegfü } \\
\text { Császár körte } \\
\text { Dániel körte } \\
\text { Debreceni nagy körte } \\
\text { Fülöp bergamott } \\
\text { Gornelis Budaörs } \\
\text { Grand Champion } \\
\text { Júliusi lapos cukor } \\
\text { Király körte } \\
\text { Kerek körte } \\
\text { Melló bárónő } \\
\text { Montreal } \\
\text { Marianna } \\
\text { Naika } \\
\text { Nocika körte } \\
\text { Őszi parázs körte } \\
\text { Őszi vajkörte } \\
\text { Piros búzás körte } \\
\text { Ráckevei körte } \\
\text { Saint Waast } \\
\text { Sárga Bácska körte } \\
\text { Sarolta } \\
\text { Solani vajkörte } \\
\text { Solymári cukor } \\
\text { Tihanyi vadkörte } \\
\text { Társulati esperes } \\
\text { Vecsei II. } \\
\text { Zöld Magdolna } \\
\text { 4/6 }\end{array}$ \\
\hline
\end{tabular}


Table 1. continued

\begin{tabular}{|c|c|c|c|c|c|}
\hline \multicolumn{6}{|c|}{ Resistance/susceptibility level of genotypes } \\
\hline $\begin{array}{c}\text { I. Resistant } \\
\text { (no infestation) }\end{array}$ & $\begin{array}{l}\text { II. Highly tolerant } \\
\text { (negligible } \\
\text { infestation) }\end{array}$ & $\begin{array}{l}\text { III. Slightly } \\
\text { susceptible } \\
\text { (light damage) }\end{array}$ & \multicolumn{2}{|c|}{$\begin{array}{l}\text { IV. Susceptible } \\
\text { (medium damage) }\end{array}$} & $\begin{array}{l}\text { V. Highly susceptible } \\
\text { (heavy damage) }\end{array}$ \\
\hline & & & $\begin{array}{l}\text { Héber körte } \\
\text { Hertich } \\
\text { Hindenburg } \\
\text { Hofmanné féle körte } \\
\text { Hóka körte } \\
\text { Homoki körte } \\
\text { Horváth körte } \\
\text { Hosszú zöld körte } \\
\text { Janne } \\
\text { Jó körte } \\
\text { Kabosdi körte } \\
\text { Kakas körte } \\
\text { Károlyi körte } \\
\text { Kedves körte } \\
\text { Kelenvölgyi körte } \\
\text { Késői bör Pákozd } \\
\text { Klára trió körte } \\
\text { Kongresszus } \\
\text { Korai szagos körte } \\
\text { Korai vérbélü } \\
\text { Köcsög körte } \\
\text { Körte 215 } \\
\text { Körte 219 } \\
\text { Kravas } \\
\text { Leányfalusi piros } \\
\text { Lincoln } \\
\text { Lipcsei retek } \\
\text { Lörinc körte } \\
\text { Lucas Sándor } \\
\text { Macskafejü körte } \\
\text { Mandula körte } \\
\text { Mária Lujza } \\
\text { Márianosztrai } \\
\text { Mézes körte } \\
\text { Mézes körte Budaörs } \\
\text { Mézkörte Érd } \\
\text { Méznár } \\
\text { Miklós } \\
\text { Mogyoródi körte } \\
\text { Mogyoródi } 2 . \\
\text { Monchallard } \\
\text { Moonalen } \\
\text { ala }\end{array}$ & $\begin{array}{l}\text { Tehénláb körte } \\
\text { Téli Csíkos körte } \\
\text { Totleben tábornok } \\
\text { Totyakos császár } \\
\text { Vadkörte } \\
\text { Váli körte } \\
\text { Vanguelin } \\
\text { Váraljai nyári körte } \\
\text { Váraljai 4. } \\
\text { Vécsi I. } \\
\text { Vérbélü } \\
\text { Véres körte } \\
\text { Vérteskozmai } \\
\text { Vertné körtéje } \\
\text { Vilmos körte } \\
\text { Virgonkuse } \\
\text { Vörös búza körte } \\
\text { Wienne diadala } \\
\text { A4-15/2-II. } \\
\text { B/1 } \\
\text { B/2-18/2 } \\
\text { B/3 } \\
\text { K-14 } \\
\text { K-21 } \\
\text { K-28 } \\
\text { K-35 } \\
\text { K-36 } \\
\text { K-40 } \\
\text { K-63 } \\
\text { K-66 } \\
\text { K-67 } \\
\text { K-69 } \\
\text { SzU-1 } \\
\text { 2/3 } \\
\text { 9/8 } \\
\text { 3-30.TA } \\
\text { 3-32-TA } \\
\text { 3-38-TA } \\
\text { 3-51-TA } \\
\text { 500-169 } \\
\text { 30060 } \\
\text { II.A3-3/5 } \\
\text { II.A4-1/2-2 }\end{array}$ & \\
\hline
\end{tabular}

Table 2. Distribution of pear genotypes (commercial cultivars, ancient local varieties, unnamed local strains, seedlings, wild seedlings) according to their susceptibility to pear psylla infestation and damage (Újfehértó gene bank: 1996-1999, 2004-2008)

\begin{tabular}{|l|c|c|}
\hline $\begin{array}{l}\text { Resistance/ } \\
\text { susceptibility level }\end{array}$ & Number of genotypes & Per cent ratio \\
\hline $\begin{array}{l}\text { I. Resistant } \\
\text { (no infestation) }\end{array}$ & 10 & $3.5 \%$ \\
\hline $\begin{array}{l}\text { II. Highly tolerant } \\
\text { (negligible infestation) }\end{array}$ & 8 & $2.8 \%$ \\
\hline $\begin{array}{l}\text { III. Slightly susceptible } \\
\text { (light damage) }\end{array}$ & 208 & $9.8 \%$ \\
\hline $\begin{array}{l}\text { IV. Susceptible } \\
\text { (medium damage) }\end{array}$ & 31 & $73.0 \%$ \\
\hline $\begin{array}{l}\text { V. Highly susceptible } \\
\text { (heavy damage) }\end{array}$ & & $10.9 \%$ \\
\hline
\end{tabular}

can give reliable results when the investigation period is long enough to cover different years with slight and heavy infestations, too. Differences in resistance and susceptibility are much more conspicuous in years with heavy than with slight infestations. We found that resistant genotypes can be practically free of pear psylla infestation in the orchard even when other (susceptible) varieties suffered moderate or heavy damages in years of heavy infestations. In years with slight or weak infestations, on the other hand, both resistant and susceptible genotypes can evenly be free of damage. However, results of our additional observations in a large commercial fruitgrowing farm proved that highly susceptible commercial cultivars can be more or less infested even under the pressure of intense plant protection applications. 
Table 3. Pear psylla infestation to some widely grown European pear cultivars under the pressure of standard plant protection practice (Gyümölcsöskert Kft. 2009)

\begin{tabular}{|c|c|c|c|c|c|c|c|}
\hline \multirow{2}{*}{$\begin{array}{l}\text { Cultivar } \\
\text { and the site }\end{array}$} & \multirow{2}{*}{$\begin{array}{l}\text { Date of } \\
\text { observation }\end{array}$} & \multicolumn{6}{|c|}{$\begin{array}{l}\text { Infestation level at the shoots of pear trees } \\
\text { per cent distribution of shoots after scale values }\end{array}$} \\
\hline & & scale 0 & scale 1 & scale 2 & scale 3 & scale 4 & scale 5 \\
\hline \multirow{4}{*}{$\begin{array}{l}\text { Cultivar: Packams' Triumph } \\
\text { Site: Feketesár }\end{array}$} & 13 April & 70 & 12 & 8 & 6 & 4 & 0 \\
\hline & 19 May & 72 & 12 & 8 & 6 & 2 & 0 \\
\hline & 08 July & 70 & 12 & 10 & 6 & 2 & 0 \\
\hline & 12 August & 64 & 16 & 10 & & 4 & 0 \\
\hline \multirow{4}{*}{$\begin{array}{l}\text { Cultivar: Bosc kobak } \\
\text { Site: Feketesár }\end{array}$} & 13 April & 46 & 18 & 10 & 10 & 6 & 0 \\
\hline & 19 May & 70 & 10 & 14 & 4 & 2 & 0 \\
\hline & 08 July & 74 & 10 & 8 & 6 & 2 & 0 \\
\hline & 12 August & 76 & 10 & 8 & 4 & 2 & 0 \\
\hline \multirow{3}{*}{$\begin{array}{l}\text { Cultivar: Bosc kobak } \\
\text { Site: Bánfapuszta }\end{array}$} & 10 April & 76 & 12 & 6 & 1 & 1 & 4 \\
\hline & 24 May & 76 & 8 & 6 & 5 & 3 & 2 \\
\hline & 06 July & 68 & 10 & 8 & 8 & 4 & 2 \\
\hline \multirow{4}{*}{$\begin{array}{l}\text { Cultivar: Bartlett (Vilmos körte) } \\
\text { Site: Feketesár }\end{array}$} & 13 April & 68 & 12 & 8 & 8 & 4 & 0 \\
\hline & 19 May & 68 & 12 & 8 & 8 & 4 & 0 \\
\hline & 08 July & 64 & 14 & 10 & 8 & 4 & 0 \\
\hline & 12 August & 66 & 14 & 10 & 8 & 2 & 0 \\
\hline \multirow{3}{*}{$\begin{array}{l}\text { Cultivar: Bartlett (Vilmos körte) } \\
\text { Site: Bánfapuszta }\end{array}$} & 10 April & 68 & 12 & 10 & 6 & 4 & 0 \\
\hline & 24 May & 74 & 10 & 8 & 6 & 2 & 0 \\
\hline & 06 July & 64 & 14 & 10 & 8 & 4 & 0 \\
\hline \multirow{3}{*}{$\begin{array}{l}\text { Cultivar: Abate Fétel } \\
\text { Site: Bánfapuszta }\end{array}$} & 10 April & 80 & 10 & 6 & 3 & 1 & 0 \\
\hline & 24 May & 78 & 14 & 6 & 1 & 1 & 0 \\
\hline & 06 July & 78 & 10 & 6 & 4 & 2 & 0 \\
\hline
\end{tabular}

Analysing 285 different European per genotypes (commercial cultivars, ancient local varieties, unnamed local strains, seedlings, wild seedlings) originating from many different sites of Hungary we have found some 10 new resistant types (Bókoló körte, Bötermö Kálmán, Füge alakú körte, Nagyasszony körte, Nyári Kálmán, Rozs nyári körte, Viki körte, $P b-242, P b-299,0-632)$ and 7 highly tolerant ones (Cure-6, Kései Kálmán, Kieffer, Kieffer Éd, Steiner, Téli Kálmán, II. B-3-6/4, 96-16/5) (Table 1). Most of them are ancient local cultivars, and the rest are unnamed local strains. These made up $3.5+2.8$ per cent of the investigated genotypes (that is 6.3 per cent altogether), while 93.7 per cent of the investigated genotypes were susceptible to pear psylla damage (Table 2). Some 10.9 per cent of the susceptible genotypes was highly susceptible and suffered the heaviest damage each year. Recent results corroborate to earlier statements that no more than a minor portion of European per genotypes show resistance or high tolerance to pear psylla damage.

One of the earlier studies (Kocsisné et al. 2005) reported on similar observations, partly made in the same gene bank where we made or own investigations. However, their observations were made in other period of time (between the years of 1998-2003) when the pear psylla infestation was very low, as the authors clearly stressed it in their paper. This condition resulted in peculiar results, very different from the results of the present analysis. Namely, Kocsisné et al. (2005) stated that great many inspected genotypes (as much as $31 \%$ in their study!) were resistant and half of the cultivars were only scarcely infested (51\%). They regarded no more than $17 \%$ of the genotypes as "medium infested" and only $1 \%$ as "strongly infested". They regarded the low infestation levels as resistance or tolerance. These results completely contradict to any other surveys reported in world literature and also to our present analysis. For example Quarta \& Puggioni (1985) found no more than $12 \%$ of the 136 inspected genotypes (cultivars and selections) of low susceptibility and no one of them was immune (resistant). Additionally, we have to say that no more than $3.5 \%$ of the genotypes that we investigated proved to be resistant in our study and only 2.8 per cent of them were highly tolerant to pear psylla damage in the same gene bank (Table 2), instead of $31 \%$ as stated by Kocsisné et al. (2005). They classified great many such genotypes to be resistant that we found to be at least slightly susceptible or susceptible during our longterm investigations. They investigated all the available 486 genotypes in the gene bank irrespective of the ages of trees that were planted continuously from 1984 to present years. They compared older trees to younger ones and to those too that were few years old only. Contrarily, we made observation on those genotypes only the trees of which were relatively uniform in age; all of them were 10-12-years years old when we started our study, and younger trees were neglected. So, unfortunately, the results of Kocsisné et al. (2005) were unacceptable for various reasons, first of all because their statements were based on exceptionally low infestation levels that did not allow drawing any reliable conclusions on the resistance or tolerance of genotypes to pear psylla damage.

Taking earlier and present results into account - ignoring the abovementioned single publication - we can list several European pear cultivars being resistant or highly tolerant to pear psylla infestation and damage (Table 4). In the list we ignored those unnamed genotypes and wild seedlings that were not utilized as traditional or modern cultivars in the fruit growing practice. Majority of the listed cultivars are ancient local varieties grown traditionally is small gardens around the house and have not been tried to exploit in commercial plantations so far. For this reason no reliable information is available on their yield capacity and fruit quality. However, watching the two trees available of each inspected genotypes at the gene bank we inspected we have got the impression that most of the local varieties we have found to be resistant or highly tolerant seem to produce acceptable yield and acceptable fruit quality. No similar observation results are 
Table 4. Resistant pear cultivars discovered in different countries

\begin{tabular}{|c|c|c|}
\hline Author & $\begin{array}{l}\text { Resistant/tolerant } \\
\text { cultivars detected }\end{array}$ & $\begin{array}{l}\text { Geographical origin } \\
\text { of resistant genotypes }\end{array}$ \\
\hline Quarta and Puggioni 1985 & $\begin{array}{l}\text { Low susceptibility: } \\
\text { Monglow } \\
\text { Sirrine } \\
\text { Spina Carpi }\end{array}$ & Italy \\
\hline Bell and Stuart 1990 & $\begin{array}{l}\text { Resistant: } \\
\text { Erabasma } \\
\text { Karamanlika } \\
\text { Katman } \\
\text { Krupen Burnusus } \\
\text { Mednik } \\
\text { Obican Vodenac } \\
\text { Smokvarka } \\
\text { Topka } \\
\text { Zelinka } \\
\end{array}$ & $\begin{array}{l}\text { former Yugoslavia } \\
\text { (mostly present } \\
\text { Serbia) }\end{array}$ \\
\hline Bell 1992 & $\begin{array}{l}\text { Resistant: } \\
\text { Bartjarka } \\
\text { Lucele } \\
\text { Kajzerka }\end{array}$ & $\begin{array}{l}\text { former Yugoslavia } \\
\text { (mostly present } \\
\text { Serbia) }\end{array}$ \\
\hline Bell 2003 & $\begin{array}{l}\text { Resistant: } \\
\text { Jerisbasma } \\
\text { Karamanka } \\
\text { Vodenjac }\end{array}$ & $\begin{array}{l}\text { former Yugoslavia } \\
\text { (mostly present } \\
\text { Serbia) }\end{array}$ \\
\hline Robert and Raimbault 2005 & \begin{tabular}{|l|} 
Resistant: \\
D'Aout Lamer \\
Doyenné de Poitiers \\
Low susceptibility: \\
Spina Carpi \\
(Italian cultivar)
\end{tabular} & France \\
\hline Sestras et al 2009 & $\begin{array}{l}\text { Resistant: } \\
\text { Haydeea } \\
\text { Weakly susceptible: } \\
\text { Cantari } \\
\text { Imperiale } \\
\text { Lorencz Kovacs } \\
\text { Triomphe de } \\
\text { Jodoigne } \\
\text { Severinka } \\
\end{array}$ & $\begin{array}{l}\text { Romania } \\
\text { (Transsylvania) }\end{array}$ \\
\hline Present study & $\begin{array}{l}\text { Resistant: } \\
\text { Bókoló körte } \\
\text { Bőtermö Kálmán } \\
\text { Füge alakú körte } \\
\text { Nagyasszony körte } \\
\text { Nyári Kálmán } \\
\text { Rozs nyári körte } \\
\text { Viki körte } \\
\text { Highly tolerant: } \\
\text { Cure-6 } \\
\text { Kései Kálmán } \\
\text { Kieffer } \\
\text { Kieffer Éd } \\
\text { Steiner } \\
\text { Téli Kálmán }\end{array}$ & Hungary \\
\hline
\end{tabular}

available on non-Hungarian cultivars listed in Table 4. In fact, the list of resistant and highly tolerant cultivars in Table 4. may serve as a basis of selecting pear cultivars fitting to the specific requirements of the organic farming. However, different cultivars originating from different countries can react different way to local ecological conditions in countries other than their home region. Accordingly, cultivars listed in Table 4. should be planted and observed in other regions where any intention to grow them in organic farms. By the end we can conclude that there is some real hope to exploit some resistant or highly tolerant ancient or local cultivars in organic farming but further investigations are needed to estimate their yield capacity and fruit quality.

\section{References}

Bell, R.L. (1992): Additional east European Pyrus germplasms with resistance to pear psylla nymphal feeding. HortScience, 27 (5): 412-413.

Bell, L.R. (2003): Resistance to pear psylla nymphal feeding of germplasm for Central Europe. Acta Hort., (ISHS): 343-345.

Bell, R. (2009): Evaluation of Pyrus germplasm for resistance to pear psylla in the orchard. HortScience, 44: 1176.

Bell, R. L. - Stuart, C.L. (1990): Resistance in eastern European Pyrus germplasm to pear psylla nymphal feeding. HortScience, 25: 789-791.

Bell, L.R. - Puterka, G. J. (2004): Modes of host plant resistance to pear psylla: a review. Acta Hort., (ISHS), 663: 183-188.

Bell, R.L. - Zwet, T. (1998): Breeding for host resistance to pear psylla: evaluation of parental germplasm. Acta Hort. (ISHS), 484: 471-476.

Berrada, S. - Nguyen, T.X. - Lemoine, J. - Vanpoucke J. Fournier, D. (1995): Thirteen pear species evaluated for resistance to Cacopsylla pyri (Homoptera: Psyllidae).Environ. Entomol., 24 (6): 1604-1607.

Briolini, G. - Capelli, A. - Rivalta, L. - Rosati, P. (1988): Observations on Pyrus communis resistance to Psylla pyri. Acta Hort. (ISHS), 224: 211-222.

Butt, B. A. - Stuart, L.C - Bell, L.R. (1988): Feeding behavior of pear psylla (Homoptera: Psyllidae) nymphs on susceptible and resistant Pyrus germplasm. J. Econ. Entomol., 81: 1394-1397.

Harris, M.K. (1973): Host resitance to pear psylla in a Pyrus communis $x$ P.ssuriensis hybrid. Environ. Entomol., 2(5): 883-888.

Kocsisné, M.G. - Szabó, T. - Nyéki, J. - Holb, I. (2005): Körtelevélbolha károsításának vizsgálata fajtagyüjteményekben. Kertgazdaság, 37(4): 37-42.

Puterka, G. J. (1997): Interspecific variation in pear psylla (Psyllidae: Homoptera) nymphal survival and development on resistant and susceptible pear. Environ. Entomol., 26: 552-558.

Puterka, G. J. - Bell, L.R. - Jones, S.K. (1993): Ovipositional preference of pear psylla (Homoptera: Psyllidae) for resistant and susceptible pear. J. Econ. Entomol., 86: 1297-1302.

Quamme, H.A. (1984): Observations of Psylla resistance among several pear cultivars and species. Fruit Varieties Journal., 38(2): 34-36.

Quatra, R. - Puggioni, D. (1985): Survey on the variety susceptibility to per psylla. Acta Hort., 159: 77-86.

Robert,P. - Raimbault, T. (2005): Resistance of somr Pyus communis cultivars and Pyrus hybrids to the pear psylla, Cacopsylla pyri (Homoptera, Psyllidae). Acta. Hort., 671: 571-575.

Sestras, R. - Botez, C. - Ardelean, M. - Oltean, I. - Sestras, A. (2009): Response of pear genotypes to Psylla sp. Attack in Central Trannsylvania, Romania. Acta Hort. 814: 845-850.

Westigard, P.H. - Westwood, M.N. - Lombard, L. (1970): Host preference and resistance of Pyrus species to the pear psylla, Psylla pyricla Foerster. J. Amer. Soc. Hort. Sci., 99: 34-36. 